\title{
PENYAKIT KRONIS LEBIH DARI SATU MENIMBULKAN PENINGKATAN PERASAAN CEMAS PADA LANSIA DI KECAMATAN CIBINONG
}

\author{
Beningtyas Kharisma Bestari ${ }^{*}$, Dwi Nurviyandari Kusuma Wati ${ }^{2}$ \\ 1. Program Studi Sarjana Fakultas Ilmu Keperawatan, Universitas Indonesia, Depok 16424, Indonesia \\ 2. Fakultas Ilmu Keperawatan, Universitas Indonesia, Depok 16424, Indonesia \\ *E-mail: beningtyas27@gmail.com
}

\begin{abstract}
Abstrak
Kecemasan merupakan perasaan takut atau khawatir yang disebabkan oleh berbagai peristiwa yang bersifat subjektif. Penelitian ini bertujuan untuk mengetahui hubungan jumlah penyakit kronis yang dimiliki terhadap kecemasan lansia dengan penyakit kronis di wilayah binaan UPF Puskesmas Pabuaran Indah, Kecamatan Cibinong. Desain penelitian adalah deskriptif korelatif dengan pendekatan cross sectional. Sampel berjumlah 105 lansia dengan penyakit kronis, berusia 60 tahun atau lebih yang dipilih dengan teknik cluster sampling. Instrumen yang digunakan adalah Depression Anxiety Stress Scale (DASS) skala kecemasan dan kuesioner karakteristik responden. Hasil penelitian menemukan terdapat hubungan antara jumlah penyakit kronis yang dimiliki terhadap kecemasan lansia dengan penyakit kronis, $(\mathrm{p}=$ 0,004) dengan kekuatan hubungan (odd ratio) 3.549. Lansia yang memiliki lebih dari satu penyakit kronis memiliki risiko 3 kali lebih besar untuk merasa cemas. Pelayanan kesehatan disarankan untuk memberikan edukasi kesehatan dan meningkatkan peran keluarga untuk mengurangi kecemasan.
\end{abstract}

Kata kunci: kecemasan, lansia, jumlah penyakit kronis

\begin{abstract}
Multiple Chronic Diseases Increase Anxious Feeling of Community-Dwelling Elderly in Cibinong District. Anxiety is fear and worry feeling that caused by various event that subjectively. This study aimed to determine relationship amount of chronic disease towards anxiety of elderly with chronic disease in UPF Puskesmas Pabuaran Indah area, Cibinong District or Kecamatan Cibinong. Descriptive correlative design with cross-sectional approach was applied. 105 elderly with chronic disease, age 60 years or above were taken in this study, which is using cluster sampling. This research using Depression Anxiety Stress Scale (DASS): Anxiety scale and characteristics of respondent questionnaire. The results of the study found that there is a relationship between amount of chronic disease towards anxiety of elderly with chronic disease $(p=0.004)$ with the strength of significance (odds ratio) 3.549. Elderly with multiple chronic diseases has 3 times more of risk to feel anxious. Health center is advised to give health education, and increase family role to reduce anxiety
\end{abstract}

Keywords: anxiety, amount of chronic disease, elderly

\section{Pendahuluan}

Penyakit kronis merupakan penyakit dengan ciri bersifat menetap, menyebabkan ketidakmampuan pada penderitanya, dan untuk menyembuhkannya penderita perlu melakukan perawatan dalam periode waktu yang lama (Mayo, 1956 dalam Lubkin \& Larsen, 2006).
Miller (2012) menyatakan bahwa kebanyakan lansia memiliki satu atau lebih kondisi kronis. Penelitian yang dilakukan oleh National Center for Health Statistics (2003) dalam Meiner dan Lueckenotte (2006) mendapati sebanyak $62 \%$ lansia yang berusia 65 tahun atau lebih memiliki dua atau lebih kondisi atau penyakit kronis. 
Lansia berisiko mengalami penyakit kronis dikarenakan penurunan fungsi tubuh. Faktor lain yang dapat meningkatkan risiko yaitu perilaku keseharian yang kurang baik, seperti merokok, alkohol, nutrisi tidak baik, dan lainlain (WHO, 2014; Smeltzer \& Bare, 2002).

Lansia dengan penyakit kronis di Indonesia memiliki jumlah yang cukup tinggi. Sebanyak 28,53\% lansia berusia 60-69 tahun memiliki keluhan kesehatan yang berkaitan dengan penyakit kronis. Persentase ini terus meningkat pada kelompok usia yang lebih tua (Badan Pusat Statistik, 2011).

Penyakit kronis dapat menimbulkan dampak bagi kesehatan lansia, dalam hal ini kesehatan jiwa yaitu kecemasan. Kecemasan merupakan suatu perasaan dimana seseorang merasa tidak aman dan terancam atas suatu hal atau keadaan (Stuart, 2013).

Kecemasan akibat penyakit kronis berhubungan dengan penyakit kronis yang dapat menyebabkan kematian. Selain itu, kesembuhan penyakit kronis yang tidak dapat dipastikan karena proses perkembangan penyakit tidak dapat diketahui dengan pasti (Miller, 2012; Smeltzer \& Bare, 2002).

Tujuan penelitian ini untuk menggambarkan karakteristik lansia dengan penyakit kronis (usia, jenis kelamin, status marital, pendapatan, bentuk keluarga, dan jumlah penyakit kronis yang dimiliki), kecemasan lansia dengan penyakit kronis, dan mengetahui hubungan jumlah penyakit kronis yang dimiliki dengan kecemasan lansia dengan penyakit kronis di wilayah binaan UPF Puskesmas X, Kecamatan Cibinong.

\section{Metode}

Penelitian dimulai bulan Oktober 2014 hingga Juni 2015. Analisis data yang digunakan yaitu analisis univariat dan bivariat. Desain penelitian yang digunakan yaitu deskriptif korelatif dengan pendekatan cross sectional.
Pengambilan data dilakukan satu kali dengan melibatkan 105 responden lansia dengan penyakit kronis di wilayah binaan UPF Puskesmas X, Kecamatan Cibinong Kabupaten Bogor. Wilayah binaan UPF Puskesmas X terdiri dari tiga Kelurahan. Kriteria inklusi dalam penelitian ini yaitu lansia yang berusia 60 tahun atau lebih dengan penyakit kronis yang telah didiagnosa oleh tenaga medis, tinggal bersama keluarga, dan memiliki pendengaran yang baik. Adapun penyakit kronis yang diteliti yaitu hipertensi, penyakit sendi atau rematik, stroke, penyakit paru, diabetes mellitus, penyakit jantung, dan kanker (Badan Penelitian dan Pengembangan Kesehatan Kementerian Kesehatan RI, 2013).

Data penelitian diperoleh dengan menggunakan kuesioner, terdiri dari kuesioner karakteristik responden (usia, jenis kelamin, status marital, pendapatan, bentuk keluarga, dan jumlah penyakit kronis yang dimiliki) dan kuesioner Depression Anxiety Stress Scale (DASS) skala kecemasan. Kuesioner DASS terdiri dari 42 item pernyataan mengenai tanda dan gejala yang bersifat negatif, terbagi menjadi 14 item pada masing-masing skala depresi, kecemasan, dan stres (McDowell, 2006). Mengingat penelitian ini bertujuan untuk menggambarkan kecemasan lansia dengan penyakit kronis, maka skala yang digunakan yaitu kuesioner DASS skala kecemasan yang terdiri dari 14 pernyataan.

Kuesioner DASS skala kecemasan yang terdiri 14 pernyataan dengan empat pilihan jawaban yaitu skor 0 artinya tidak pernah, skor 1 artinya kadang-kadang, skor 2 artinya sering, skor 3 artinya selalu. Hasil penilaian adalah dengan menjumlahkan skor dari masingmasing item pernyataan. Nilai maksimum dari instrumen ini yaitu 42 dan nilai minimum 0 . Hasil ukur untuk kecemasan dikategorikan menjadi normal dan cemas, pengelompokkan berdasarkan median yaitu 7 . Skor $\leq 7$ merupakan normal, dan skor $>7$ artinya cemas.

Penggabungan beberapa kategori kecemasan dilakukan untuk mencegah data kehilangan 
makna. Hal ini dikarenakan tidak terpenuhinya syarat ketentuan uji chi square saat dilakukan uji analisis, yaitu terdapat sel yang memiliki nilai ekspektasi kurang dari lima lebih dari $20 \%$. Pengkategorian ini sesuai dengan kuesioner DASS kecemasan yang mengklasifikasikan kategori normal bila skor $0-7$ atau $\leq 7$ (Lovibond \& Lovibond, 1995 dalam Lam, Michalak, \& Swinson, 2005).

Instrumen karakteristik responden terdiri dari enam pertanyaan dengan pilihan jawaban. Karakteristik responden yang diteliti oleh peneliti yaitu usia, jenis kelamin, status marital, pendapatan, bentuk keluarga, jumlah penyakit kronis yang dimiliki. Hasil ukur untuk jumlah penyakit kronis yang dimiliki dikategorikan menjadi dua, yaitu satu penyakit kronis dan lebih dari satu penyakit kronis.

Hubungan jumlah penyakit kronis yang dimiliki dengan kecemasan lansia dengan penyakit kronis diuji dengan menggunakan uji chi square. Uji tersebut digunakan karena jenis data pada variabel penelitian ini merupakan data kategorik, yaitu kategori jumlah penyakit kronis yang dimiliki dan kategori kecemasan lansia dengan penyakit kronis.

\section{Hasil}

Responden pada penelitian ini adalah lansia dengan penyakit kronis yang tinggal bersama keluarga dan berusia 60 tahun atau lebih di wilayah binaan UPF Puskesmas $\mathrm{X}$, berjumlah 105 orang. Tabel 1 menjelaskan karakteritik lansia dengan penyakit kronis di wilayah binaan UPF Puskesmas X, Kecamatan Cibinong.

Tabel 1 menunjukkan bahwa karakteristik lansia dengan penyakit kronis berjenis kelamin perempuan $(70.5 \%)$, berada pada usia lansia muda (83.8\%), memiliki status janda/duda (50.5\%), mempunyai pendapatan keluarga sama dengan atau lebih besar dari upah minimum Kabupaten Bogor (55.2\%), tinggal dengan keluarga besar (50.5\%), dan memiliki satu jenis penyakit kronis $(61 \%)$ mempunyai persentase yang lebih besar dibandingkan karakteristik lainnya. Sebanyak 39\% responden memiliki lebih dari satu penyakit kronis.

Tabel 2 menunjukkan gambaran kecemasan lansia dengan penyakit kronis. Berdasarkan tabel tersebut diketahui bahwa terdapat $55.2 \%$ lansia dengan penyakit kronis yang tidak merasakan kecemasan atau normal. Namun jumlah tersebut tidak jauh berbeda dengan lansia yang mengalami kecemasan $(44.8 \%)$.

Tabel 3 menunjukkan bahwa 63.4\% lansia dengan lebih dari satu penyakit kronis mengalami kecemasan. Terdapat hubungan yang signifikan antara jumlah penyakit kronis yang dimiliki terhadap kecemasan lansia dengan penyakit kronis $(\mathrm{p}<0,05)$. Nilai odd ratio yaitu 3,549 , artinya responden yang memiliki lebih dari satu jenis penyakit kronis memiliki risiko 3 kali lebih besar untuk merasakan kecemasan dibandingkan responden yang memiliki satu penyakit kronis.

Tabel 1. Karakteristik Lansia dengan Penyakit Kronis

\begin{tabular}{lcc}
\hline \multicolumn{1}{c}{ Karakteristik Lansia } & Jumlah & Persentase \\
\hline Jenis kelamin & 31 & \\
Laki-laki & 74 & 79,5 \\
Perempuan & & \\
Usia & 88 & 83,8 \\
Lansia muda & 17 & 16,2 \\
Lansia tua-sangat tua & & \\
Status marital & 52 & 49,5 \\
Menikah & 53 & 50,5 \\
Janda/ duda & & \\
Pendapatan & 47 & 44,8 \\
< Upah minimum Kabupaten Bogor* & 58 & 55,2 \\
Z Upah minimum Kabupaten Bogor & & \\
Bentuk keluarga & 32 & 30,5 \\
Keluarga inti & 53 & 50,5 \\
Keluarga besar & 20 & 19,0 \\
Keluarga lainnya & & \\
Jumlah penyakit kronis yang & & \\
dimiliki & & \\
Satu penyakit kronis & & \\
Lebih dari satu penyakit kronis & 64 & 39,0 \\
\hline
\end{tabular}

Ket: * Upah minimum Kabupaten Bogor tahun 2015 Rp 2.590.000 (Gubernur Jawa Barat, 2014) 
Tabel 2. Kecemasan Lansia dengan Penyakit Kronis

\begin{tabular}{lcc}
\hline \multicolumn{1}{c}{ Kecemasan } & Frekuensi & Persentase \\
\hline Normal & 58 & 55,2 \\
Cemas & 47 & 44,8 \\
\hline
\end{tabular}

Tabel 3. Hubungan Jumlah Penyakit Kronis yang Dimiliki dengan Kecemasan Lansia dengan Penyakit Kronis

\begin{tabular}{|c|c|c|c|c|c|}
\hline \multirow{3}{*}{$\begin{array}{c}\text { Variabel } \\
\text { Jumlah } \\
\text { Penyakit Kronis }\end{array}$} & \multicolumn{4}{|c|}{ Kecemasan } & \multirow{3}{*}{$\mathbf{p}$} \\
\hline & \multicolumn{2}{|c|}{ Normal } & \multicolumn{2}{|c|}{ Cemas } & \\
\hline & $\mathbf{n}$ & $\%$ & $\mathbf{n}$ & $\%$ & \\
\hline $\begin{array}{l}\text { Satu penyakit } \\
\text { kronis }\end{array}$ & 43 & 67,2 & 21 & 32,8 & $\begin{array}{c}0,004 * \\
(\text { Odd }\end{array}$ \\
\hline $\begin{array}{l}\text { Lebih dari satu } \\
\text { penyakit kronis }\end{array}$ & 15 & 36,6 & 26 & 63,4 & $\begin{array}{c}\text { ratio } \\
3,549)\end{array}$ \\
\hline
\end{tabular}

Ket: $* \mathrm{p}<0,05$ (memiliki hubungan yang signifikan)

\section{Pembahasan}

Hasil penelitian menunjukkan adanya hubungan yang signifikan antara jumlah penyakit kronis yang dimiliki dengan kecemasan. Lansia yang memiliki penyakit kronis lebih dari satu memiliki risiko 3 kali lebih besar untuk merasakan kecemasan dibandingkan dengan lansia yang memiliki satu penyakit kronis. Stuart (2013) menyatakan kecemasan seseorang dapat dipengaruhi oleh masalah kesehatan yang dialaminya.

Berdasarkan pengertian dan karakteristiknya, penyakit kronis merupakan gangguan kesehatan dengan proses penyakit yang lama dan membutuhkan pengobatan dan pengawasan dalam jangka waktu yang lama pula (Smeltzer \& Bare, 2002). Selain itu, kondisi kronis menimbulkan berbagai keterbatasan pada penderitanya. Individu dengan penyakit kronis perlu melakukan penyesuaian terhadap keterbatasan yang ditimbulkan akibat penyakit kronis.

Turner dan Kelly (2000) menyatakan bahwa penyakit kronis menyebabkan keterbatasan dalam hal gaya hidup dan dalam melakukan kegiatan atau pekerjaan. Dalam penelitian tersebut, individu yang tidak bisa menyesuaikan diri dapat mengalami gangguan kejiwaan, salah satunya kecemasan. Penelitian Wells, Golding, dan Burnam (1988) menyatakan bahwa lebih dari $11 \%$ individu dengan kondisi medis kronis mengalami kecemasan dalam 6 bulan terakhir (dihitung dari waktu saat wawancara).

Semakin banyak penyakit kronis yang dimiliki maka semakin banyak pula keterbatasan yang ditimbulkan. Hal ini didukung oleh penelitian Ralph, Mielenz, Parton, Flatley \& Thorpe (2013) yang menyatakan bahwa persentase keterbatasan dalam aktivitas dasar sehari-hari meningkat seiring dengan jumlah kondisi kronis yang dimiliki. Dengan beban yang semakin berat, perasaan khawatir dan takut dalam menjalani kehidupan dengan kondisi tersebut semakin meningkat.

Kecemasan pada lansia dengan penyakit kronis juga ditimbulkan akibat tidak adanya kepastian akan kesembuhan penyakit. Berdasarkan teori diketahui bahwa karakteristik penyakit kronis yaitu jarang yang dapat disembuhkan (Centers for Disease Control and Prevention, 1998 dalam Meiner \& Lueckenotte, 2006). Penderita cenderung hidup bersama dengan penyakit kronis yang dimilikinya.

Penyakit kronis menyebabkan kematian pada penderitanya. Penelitian Joshi, et al., (2006) yang dilakukan di India diketahui bahwa penyakit kronis dan penyakit tidak menular menjadi penyebab kematian tertinggi. Hal ini juga terjadi di Indonesia. Kecenderungan kematian akibat penyakit tidak menular seperti kanker, diabetes, jantung, dan PPOK terus meningkat pada setiap tahunnya (Kementerian Kesehatan RI, 2012). Keadaan tersebut menimbulkan kecemasan pada individu yang menderitanya.

Penyakit kronis yang dapat menyebabkan kematian menimbulkan rasa khawatir pada indi- 
vidu yang menderitanya. Penelitian Wijayanti dan Lailatushifah (2012) menunjukkan bahwa sebanyak $6.67 \%$ pasien dengan diabetes mengalami kecemasan terhadap kematian yang tinggi, dan $36.67 \%$ pasien dengan kecemasan kematian yang sedang, dan sisanya mengalami kecemasan yang ringan. Hal tersebut menunjukkan bahwa individu dengan penyakit kronis memiliki kecemasan akan masa depan kesehatan dan terdapat kekhawatiran akan penyakitnya yang dapat menyebabkan kematian.

Penelitian ini menunjukkan bahwa perawat perlu melakukan asuhan keperawatan mulai dari pengkajian hingga melakukan evaluasi terhadap intervensi keperawatan yang dilakukan untuk mencegah rasa cemas semakin memburuk. Perawat dapat mendemonstrasikan teknik napas dalam, dan memotivasi lansia dengan penyakit kronis untuk dapat mencurahkan apa yang dirasakannya pada orang lain, misalnya keluarga. Pencegahan perlu dilakukan agar jumlah penyakit kronis yang dimiliki lansia tidak bertambah dengan memotivasi lansia untuk dapat menjaga pola hidupnya. Keluarga dengan lansia juga dimotivasi untuk mendukung pola hidup sehat lansia.

Keterbatasan penelitian ini yaitu terkadang keluarga memberikan intervensi saat lansia memberikan jawaban mengenai rasa cemas yang dirasakan lansia. Hal ini membuat peneliti perlu mengkonfirmasi kembali jawaban lansia dengan penyakit kronis, sesuai dengan apa yang dirasakannya. Mayoritas responden merupakan lansia yang berobat di puskesmas, dan hanya sebagian kecil yang berobat di Rumah Sakit berdasarkan rujukan dari puskesmas. Kondisi ini membuat kurang bervariasinya responden, karena tidak menutup kemungkinan lansia yang berobat ke rumah sakit lebih cemas dibandingkan lansia yang berobat di puskesmas karena alasan tingkat keparahan penyakitnya.

\section{Kesimpulan}

Penelitian ini menyimpulkan bahwa mayoritas lansia dengan penyakit kronis berjenis kelamin perempuan, berada pada usia lansia muda, berstatus janda/duda, memiliki pendapatan keluarga sama dengan atau lebih besar dari upah minimum Kabupaten Bogor, tinggal bersama keluarga besar, dan memiliki satu jenis penyakit kronis. Lebih dari setengah responden tidak mengalami kecemasan atau normal, yaitu $55.2 \%$.

Terdapat $63.4 \%$ lansia yang memiliki lebih dari satu penyakit kronis merasakan kecemasan. Hasil uji statistik didapatkan adanya hubungan yang siginifikan antara jumlah penyakit kronis yang dimiliki dengan kecemasan pada lansia dengan penyakit kronis.

Adapun saran dari penelitian ini yaitu diharapkan pelayanan kesehatan dapat memberikan edukasi kesehatan mengenai penyakit kronis dan dampak yang ditimbulkan oleh penyakit kronis, serta memberikan motivasi dan meningkatkan peran keluarga dalam mengatasi atau mengurangi kecemasan dalam program bina keluarga lansia. Selain itu, penelitian selanjutnya dapat menggunakan metode yang lebih kompleks, misalnya dalam hal desain penelitian dan teknik sampling (ER, INR,TN).

\section{Referensi}

Badan Penelitian dan Pengembangan Kesehatan Kementerian Kesehatan RI. (2013). Riset Kesehatan Dasar 2013. Diperoleh dari http://www.litbang.depkes.go.id/sites/downloa d/rkd2013/Laporan_Riskesdas2013.PDF

Badan Pusat Statistik (BPS). (2011). Statistik penduduk lanjut usia Indonesia 2011. Jakarta: Badan Pusat Statistik.

Gubernur Jawa Barat. (2014). Keputusan Gubernur Jawa Barat Nomor: 561/Kep.1581Bangsos $/ 2014$ tentang upah minimum kabupaten/kota di Jawa Barat tahun 2015. Diperoleh dari http://www.jababekainfrastruk tur.com/assets/uploads/files/SK\%20Gubernur \%20Jabar\%20Ttg\%20UMK\%202015\%20di\% 20Jabar.pdf 
Joshi, R., Cardona, M., Iyengar, S., Sukumar, A., Raju, C. R., Raju, K. R., ........Neal, B. (2006). Chronic diseases now a leading cause of death in rural india-mortality data form the Andhra Pradesh Rural Health Initiative. International Journal of Epidemiology, 35 (6), 1522-1529. doi: 10.1093/ije/dyl168.

Kementerian Kesehatan RI. (2012). Buletin jendela: Data dan informasi kesehatan penyakit tidak menular. Jakarta: Kementerian Kesehatan RI.

Lam, R.W., Michalak, E.E., \& Swinson, R.P. (2005). Assessment scales in depression, mania, and anxiety. United Kingdom: Taylor \& Francis Group.

Lubkin, I.M., \& Larsen, P.D. (2006). Chronic illness: Impact and interventions (6th Ed.). USA: Jones and Bartlett Publishers Inc.

McDowell, I. (2006). Measuring health: A guide to rating scales and questionnaires. New York: Oxford University Press, Inc.

Meiner, S.E., \& Lueckenotte, A.G. (2006). Gerontologic nursing (3rd Ed.). Missouri: Mosby Elsevier.

Miller, C.A. (2012). Nursing for wellness in older adults (6th Ed.). China: Wolters Kluwer Health, Lippincott Williams \& Wilkins.

Ralph, N.L., Mielenz, T.J., Parton, H., Flatley, A., \& Thorpe, L.E. (2013). Multiple chronic conditions and limitations in activities of daily living in a community-based sample of older adults in new york city, 2009. Preventing Chronic Disease, 10. DOI: http://dx.doi. org/10.5888/pcd10.130159.

Smeltzer, S. C., Bare, B. G. (2002). Buku ajar keperawatan medical bedah Brunner \& Suddarth (Edisi 8, Volume 1). (Agung Waluyo, I. Made Karyasa, Julia, H.Y. Kuncara, \& Yasmin Asih, Penerjemah). Jakarta: Penerbit Buku Kedokteran EGC.

Stuart, L. (2013). Principles and practice of psychiatric nursing (10th Ed.). St. Louis: Mosby Elsevier.

Turner, J., \& Kelly, B. (2000). Emotional dimensions of chronic disease. Western journal of medicine, 172 (2), 124-128.

Wells, K. B., Golding, J. M., \& Burnam, M. A. (1988). Psychiatric disorder in a sample of general population with and without chornic medical conditions. Am J Psychiatry, 14 (8), 976-981. doi: 10.1176/ajp.145.8.976

Wijayanti, A., \& Lailatushifah, S.N.F. (2012). Kebermaknaan hidup dan kecemasan terhadap kematian pada orang dengan diabeter mellitus. InSight: Jurnal Ilmiah Psikologi, 10 (1), 4963. http://fpsi.mercubuana-yogya.ac.id/.

World Health Organization (WHO). (2014). Noncommunicable diseases. Diperoleh dari http://www.who.int/mediacentre/factsheets/fs3 55/en/ 
